\title{
ASSESSMENT OF POSSIBLE APPLICATION OF GEOCHEMISTRY TO DISTINGUISH LIMNIC AND PARALIC COAL-BEARING PARTS OF THE CARBONIFEROUS IN THE UPPER SILESIAN COAL BASIN
}

\section{OCENA MOŻLIWOŚCI ZASTOSOWANIA BADAŃ GEOCHEMICZNYCH DO IDNENTYFIKACJI LIMNICZNYCH I PARA LICZNYCH WARSTW KARBONU PRODUKTYWNEGO GÓRNOŚLĄSKIEGO ZAGLĘBIA WĘGLOWEGO}

The paper presents the results of geochemical analyses of samples from the Poruba Beds of the paralic series and from the Zaleskie Beds of the limnic series Upper Silesian Coal Basin (USCB). The contents of the following trace elements and oxides were evaluated using spectrometric method: $\mathrm{Cr}$, $\mathrm{Th}$, $\mathrm{U}, \mathrm{V}, \mathrm{AL}_{2} \mathrm{O}_{3}, \mathrm{MgO}, \mathrm{K}_{2} \mathrm{O}, \mathrm{P}_{2} \mathrm{O}_{5}$.

The following indicators, most commonly used in chemostratigraphy and in the identification of the marine and non-marine sediments ratios, were analyzed: $\mathrm{U}, \mathrm{Th}, \mathrm{Th} / \mathrm{U}, \mathrm{K}_{2} \mathrm{O}, \mathrm{Th} / \mathrm{K}_{2} \mathrm{O}, \mathrm{P}_{2} \mathrm{O}_{5}, \mathrm{Al}_{2} \mathrm{O}_{3}, \mathrm{P}_{2} \mathrm{O}_{5}$ / $\mathrm{Al}_{2} \mathrm{O}_{3}, \mathrm{~V}, \mathrm{Cr}, \mathrm{V} / \mathrm{Cr}$, and $\left(\mathrm{K}_{2} \mathrm{O} / \mathrm{Al}_{2} \mathrm{O}_{3}\right) /\left(\mathrm{MgO} / \mathrm{Al}_{2} \mathrm{O}_{3}\right)$. The research showed that those ratios may be used to identify sedimentary environments and geochemical correlations of the sedimentary rock sequences in the USCB. Geochemical ratios discussed in the paper allowed distinguishing two populations of samples representing paralic and limnic series.

Keywords: geochemistry, stratigraphic correlation, geochemical ratios, trace-elements

W artykule zaprezentowano wyniki badań geochemicznych próbek z warstw Porębskich z serii paralicznej i z warstw Załęskich z serii limnicznej Górnośląskiego Zagłębia Węglowego (GZW). Metodą spektrometryczną oznaczono zawartość następujących pierwiastków śladowych i tlenków: Cr, Th, U, V, $\mathrm{AL}_{2} \mathrm{O}_{3}, \mathrm{MgO}, \mathrm{K}_{2} \mathrm{O}, \mathrm{P}_{2} \mathrm{O}_{5}$. Analizowano najczęściej stosowane, w chemostratygrafii i identyfikacji osadów morskich i niemorskich, wskaźniki: $\mathrm{U}$, Th, Th/U, $\mathrm{K}_{2} \mathrm{O}, \mathrm{Th} / \mathrm{K}_{2} \mathrm{O}, \mathrm{P}_{2} \mathrm{O}_{5}, \mathrm{Al}_{2} \mathrm{O}_{3}, \mathrm{P}_{2} \mathrm{O}_{5} / \mathrm{Al}_{2} \mathrm{O}_{3}, \mathrm{~V}, \mathrm{Cr}, \mathrm{V} / \mathrm{Cr}$, $\left(\mathrm{K}_{2} \mathrm{O} / \mathrm{Al}_{2} \mathrm{O}_{3}\right) /\left(\mathrm{MgO} / \mathrm{Al}_{2} \mathrm{O}_{3}\right)$. Badania wykazały, że wskaźniki te z powodzeniem mogą być stosowane do identyfikacji środowisk sedymentacyjnych i korelacji sekwencji skał osadowych w GZW.

Geochemiczne wskaźniki zastosowane w pracy pozwoliły wyróżnić dwie populacje próbek reprezentujących serię paraliczną i limniczną.

Słowa kluczowe: geochemia, korelacja stratygraficzna, wskaźniki geochemiczne, pierwiastki śladowe

* INSTITUTE OF APPLIED GEOLOGY, FACULTY OF MINING AND GEOLOGY, SILESIAN UNIVERSITY OF TECHNOLOGY, UL. AKADEMICKA 2A, 44-100 GLIWICE, POLAND

\# Corresponding author: Magdalena.Kokowska-Pawlowska@polsl.pl 


\section{Introduction}

Geochemistry deals with the geochemical nature of sediments. It uses the content of elements in rocks to correlate the sequences of sedimentary rocks. Geochemical research on rocks with the aim of correlation has been conducted at least since the 1970s. Recently, such research has even broader usage in mining and exploration geology.

The elemental composition of sediments varies notably and depends on the characteristics of a clastic material and its provenance, conditions of sedimentation, paleoclimate, and diagenesis (Grygar \& Popelka, 2016; Ratcliffe et al., 2008; Pearce et al., 2010). Even apparently homogeneous sequences exhibit some differences in chemical composition, which make chemo correlation a commonly usable tool (especially in the petroleum industry) to determine stratigraphy and to correlate drill holes (Ehrenberg \& Siring, 1992; Racey et al., 1995; Pearce et al., 1999; 2005a, 2005b; Wray, 1999; Ratcliffe et al., 2004, 2006). It is also commonly used for correlation as a supplementary tool in palaeontological, palynological, mineralogical, and sedimentological research.

Recent geochemical research is frequently used to identify various depositional environments. In the case of rock sequence research, where precise sampling is not possible and palaeontological data are missing, geochemical research is the only possible method that allows identifying the sedimentary environment and correlation of rock sequence. Chemostratigraphical research was conducted for the Upper Carboniferous of the English Midlands area (West Midlands and East Midlands), Southern Wales, the North Sea area (Great Britain; Pearce et al., 2010), the Netherlands (Kombrik et al., 2008), and the Bohemian Massif (Germany; Dill et al., 1991), for example.

The aim of this study is to compare the geochemical character of the paralic and limnic series deposits, and assess the possibilities of usage of certain geochemical indices in the identification of sedimentary paleoenvironments of Carboniferous sequences of the Upper Silesian Coal Basin.

\section{Present level of research}

\subsection{History of trace element research in the Upper Silesian Coal Basin}

Geochemical research concerning the presence of trace, minor, and major elements in the Upper Silesian Coal Basin (USCB) started in the 1950s (Roga et al., 1958; Ryczek, 1959). They were mainly pertaining to the content of elements in coal and ash. At first, the research concentrated on the analysis of a relationship between each element with the organic or mineral matter in coal (Kuhl et al., 1960; Mielecki \& Krzyżanowska, 1961). This research allowed connecting the presence of elements such as $\mathrm{Ca}, \mathrm{Mg}, \mathrm{Zn}, \mathrm{Pb}, \mathrm{Cd}, \mathrm{Ni}, \mathrm{Co}$, and $\mathrm{Cu}$ in coal mainly with the mineral matter (Parzentny, 1989b, 1990). The presence of $\mathrm{Zn}, \mathrm{Pb}, \mathrm{Cd}, \mathrm{Ni}, \mathrm{Co}$, and $\mathrm{Cu}$ may relate to sulphides and clay minerals, while $\mathrm{Ca}, \mathrm{Mg}, \mathrm{Mn}$ may relate to carbonates (Winnicki, 1973; Widawska-Kuśmierska, 1981; Parzentny, 1989b; Diehl et al., 2004). It is worth mentioning that elements such as $\mathrm{Si}, \mathrm{Ti}, \mathrm{Al}$, and $\mathrm{K}$ in coal are often associated with quartz and clay minerals (Liu et al., 2001), while $\mathrm{K}, \mathrm{B}, \mathrm{Cu}, \mathrm{Ti}, \mathrm{Ga}, \mathrm{Cr}$, and $\mathrm{Cs}$ may also be associated with other aluminosilicates (Alastuey et al., 2001; Huggins and Huffman, 2004; Zhang et al., 2004).

Further attempts to establish the link between trace elements and the organic and inorganic matter in coal were based on studying changes of their amounts in high- and low-ash coal 
(Parzentny, 1989b). Based on the content of certain elements in fractions of coal characterised by various densities, there were attempts to establish a relation between the quantities of elements with certain constituents of coal (Winnicki, 1973; Parzentny, 1989b; Lewińska-Preis et al., 2001). Relationships between certain elements and some coal constituents (e.g., $\mathrm{Zn}, \mathrm{Pb}$, and $\mathrm{Cd}$ ) with vitrinite and inertinite were also confirmed.

Geochemical research of coal in the Upper Silesian Coal Basin has also been conducted to establish the average content of elements and to settle the general and local regularity of their allocation in coal deposits (Parzentny, 1989a, 1991; Hanak \& Kokowska-Pawłowska, 2004, 2006a). Some of the elements show a low indicator of concentration variability in coal and lack clear enrichment or impoverishment zones, which implicate their low mobility and probable syngeneic origin. Among them are V, Cr, Ga, Ni, and Co (Różkowska \& Ptak, 1995). The concentration of $\mathrm{Pb}, \mathrm{Zn}, \mathrm{Cu}$, and $\mathrm{Ba}$ in coal indicate a very high horizontal and vertical diversification in the deposits. Geological and geochemical presuppositions imply their epigenetic origin (Różkowska \& Ptak, 1995).

Recently, the research on the association of elements in coal has been analysed through its environmental aspect. Exploitation, processing, and usage of coal relate to the possible emissions of dust and gases that contain many harmful substances, such as sulphur and nitrogen oxides, chlorine, fluorine, mercury vapours, and heavy metals (Dubiński et al., 2005). The knowledge of concentration of trace and minor elements (including radioactive elements) in coal has led to many cognitive and practical studies concerning the assessment of efficacy of certain methods of mechanical processing in obtaining coal that is free from noxious constituents and development of technology enabling recovery of elements (Spears, 1965; Parzentny, 1989a, 1989b, 1990; Różkowska, 1993; Różkowska \& Ptak, 1995; Olkuski \& Stala-Szlugaj, 2009).

Geochemical research concerning the presence of trace and minor elements in the Upper Silesian Coal Basin has, thus far, seldom been conducted and was primarily concerned with rocks from interlayers or from the roof and floor of the coal seams. The issue connected with the concentration of trace elements in roof and floor deposits was studied by Chodyniecka et al. (1994) and Hanak and Kokowska-Pawłowska (2003, 2004, 2006b), among others. They proved that the trace element contents in coal are diverse and strongly variable.

Many factors affected various facies environment, diagenetic and epigenetic processes, and mineralogical and petrographic character of rocks (Adamczyk, 1998; Chodyniecka et al., 1994; Hanak \& Kokowska-Pawłowska, 2006a). The outcome of research concerning the trace element content in rocks accompanying the coal seam was used to correlate them with their chemical composition (Adamczyk, 1998). The presence of interlayers (mostly claystone) and agglomerations of clay, carbonate, and sulphide minerals has a major effect on content and allotment of most elements in coal deposits (Chodyniecka, 1973; Dill et al., 1991; Parzentny, 1999).

Geochemical research aiming for chemostratigraphic correlation and identification of marine, brackish, and freshwater sediments has not been conducted so far for the Upper Silesian Coal Basin.

\subsection{Geochemical ratios applied in chemostratigraphic research}

Geochemical research used in chemostratigraphy is based on the content of elements and their relationships demonstrated by geochemical ratios. The different geochemical character, even on apparently lithologically homogeneous rock sequences, allows their correct correlation. Marine horizons are commonly used in correlating rock sequences. Geochemical research allows identify- 
ing the real marine horizons, even if the palaeontological data is missing. Marine bands are broadly used in stratigraphic correlation in coal, oil, and gas geology. There are many indicators that allow to distinguish sediments that are deposited in marine and non-marine sedimentary environments. It has been noted that marine mudstone and claystone vary geochemically (Adams \& Weaver, 1958; Archard \& Trice, 1990; Leeder et al., 1990; Davies \& McLean, 1996; O’Mara \& Turner, 1997).

Marine sediments characterized by an increase in the content of trace elements, especially: uranium (U), molybdenum (Mo), vanadium (V). U, Mo, V and to a lesser extent $\mathrm{Cr}$ and Co, tend to be more soluble under oxidising conditions and less soluble under reducing conditions, resulting in authigenic enrichments in oxygen-depleted sedimentary facies (Tribovillard et al., 2006). The enrichment in uranium and other trace elements, which is present in sediments deposited in anaerobic conditions and its main source of origin is seawater (Algeo \& Maynard, 2004; Taylor \& McLennan, 1985; Tribovillard et al., 2006; Xu et al., 2012).

Classic 'marine bands' are usually represented by black shales with higher levels of uranium (U), a high level of gamma radiation, and the presence of goniatites (Pearce et al., 2010). Uranium is mostly concentrated in organic matter in shales deposited in an anoxic environment (Adams \& Weaver, 1958; Archard \& Trice, 1990). Davies and McLean (1996) and O’Mara and Turner (1997), based on research of the Namurian in the English Midlands (West Midlands and East Midlands), stated that marine sediments are characterised by a higher $U$ content ( $U>6 \mathrm{ppm})$. Leeder et al. (1990) presented a similar conclusion concerning the $U$ content in Namurian and Westphalian sediments around the North Sea.

Marine dark mudstone contains more $U$ than the freshwater and brackish ones, as it was deposited in a toxic environment where $\mathrm{U}$ is present as a more soluble $\mathrm{U}^{6+}$. In marine sediments that are deposited in an anoxic environment, insoluble $\mathrm{U}^{4+}$ is present. In sediments containing a lot of organic matter, $U$ may be captured and bound with an amorphous organic matter, plant fossils, or clay minerals (Archard \& Trice, 1990; Leeder et al., 1990). Uranium is mostly concentrated in organic matter cumulated in shales deposited in anoxic environments (Adams \& Weaver, 1958; Archard \& Trice, 1990; Leeder et al., 1990; Davies \& McLean, 1996; O’Mara \& Turner, 1997).

The $U$ content of sediments is a combination of authigenic and detrital components, and authigenic $U$ is a suitable indicator of redox conditions (Jones \& Manning, 1994). Per Wignall and Myers (1988), authigenic $U$ can be calculated as $U_{\text {aut }}=U_{\text {tot }}-T h / 3$, with $T h / 3$ as an estimate of the detrital $U$ fraction in mudstone. Reducing conditions may precipitate $U$ to enrich the sediment in 'autogenic' (nondetrital) U.

Marine sediments are characterised by a low ratio of $T h / U$. According to Davies and McLean (1996), the $T h / U$ ratio for marine sediments is 3.8, Hollywood and Whorlow (1993) stated that the ratio is below 3, and Adams and Weaver (1958) established the boundary ratio as $T h / U=2$. The research conducted by Kombrink et al. (2008) for the Upper Carboniferous sediments from the Netherlands showed that the ratio introduced by Hollywood and Whorlow (1993) $(T h / U=3)$ has a broader usage. Brackish sediments may be mistakenly classified as marine sediments if the higher ratio is adopted. According to Davies and McLean (1996), the Th (ppm)/ $\mathrm{K}_{2} \mathrm{O}(\%)$ ratio is below 6 (or below $6 \times 10^{-4}$ when it keeps the value as dimensionless weight), which also points to marine sediments.

In geochemical characteristics of the marine band, Pearce et al. (2010) used Mo, Cu, Zn, Ni, $\mathrm{V}, \mathrm{Zr}$, and $\mathrm{P}_{2} \mathrm{O}_{5}$ in addition to Th and $\mathrm{U}$. The participation of these constituents is expressed by their ratio to $\mathrm{Al}_{2} \mathrm{O}_{3}$ to level the variations of the mineral composition of rocks. In marine sediments, the amount of $\mathrm{P}_{2} \mathrm{O}_{5}$ is usually higher, and 0.02 is taken as a boundary value of the $\mathrm{P}_{2} \mathrm{O}_{5}$ / $\mathrm{Al}_{2} \mathrm{O}_{3}$ ratio. While using this ratio, it is worth remembering that $\mathrm{P}_{2} \mathrm{O}_{5}$ may be higher in mudstone 
with Lingula and fish scales. A high accumulation of heavy minerals in rock may also cause the rise of the amount of $\mathrm{P}_{2} \mathrm{O}_{5}$ and U. To identify marine and non-marine claystone, Roaldset (1978) proposed the $\mathrm{MgO} / \mathrm{Al}_{2} \mathrm{O}_{3}$ to $\mathrm{K}_{2} \mathrm{O} / \mathrm{Al}_{2} \mathrm{O}_{3}$ ratio. However, Roaldset (1978) propose the diagram that is used to separate marine and non-marine creations, and as a criterion of this separation, point to the $\mathrm{MgO} / \mathrm{Al}_{2} \mathrm{O}_{3}$ ratio regardless of the $\mathrm{K}_{2} \mathrm{O} / \mathrm{Al}_{2} \mathrm{O}_{3}$ ratio. Sediments characterised by the $\mathrm{MgO} / \mathrm{Al}_{2} \mathrm{O}_{3}$ ratio that is higher than 0.05 are marine sediments.

Moreover, marine sediments are characterised by larger concentration of vanadium than limnic sediments (Breit \& Wanty, 1991; Kombrink et al., 2008). The exact boundary value is not known and identification of sedimentary environment is based on the average value of $\mathrm{V}$ for each rock series. Marine and lacustrine sediments may also be identified by the $\mathrm{V} / \mathrm{Cr}$ ratio. Sediments with the ratio higher than 1.5 , are the marine rocks and those with the ratio from 0.2 to 1.5 are lacustrine (Adamczyk, 1998; Dill et al., 1991).

\section{Sampling and methodology}

The samples (claystone and sandy claystone) were taken from limnic and paralic series of USCB from the area of Zabrze and Rybnik (Fig. 1-2). Paralic series includes mudstone with claystone and sandstone interlayers, in which participation is not higher than $30 \%-40 \%$. The

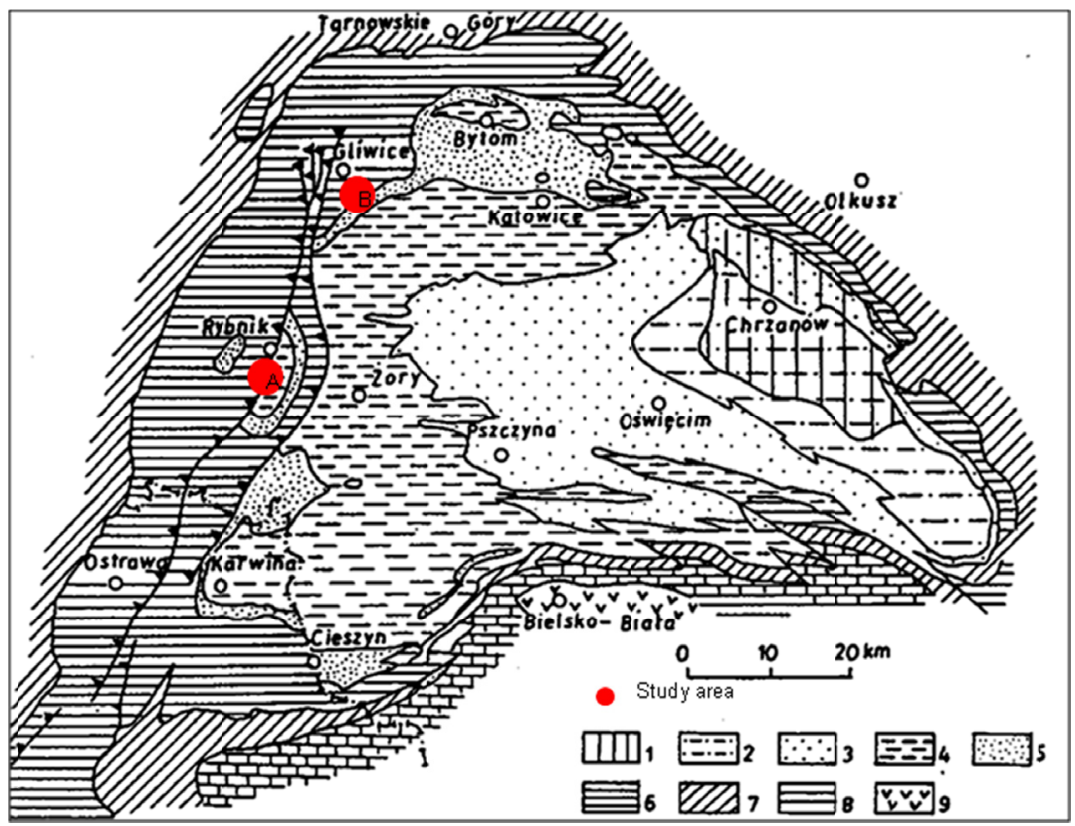

Fig. 1. Location of the study area in the main geological zone in the Upper Silesian Coal Basin (Poland) (after Kotas, 1982, modified).

Explanations: 1 - Kwaczała Arkose, 2 - Libiąż layers, 3 - Łaziska layers, 4 - Mudstones Series,

5 - Upper Silesian Sandstone Series, 6 - Paralic Series, 7 - diastrophic marine sediments, 8 - Devonian carbonate and clastic marine sediments, 9 - metamorphic rocks, A - study area coal mines Chwałowice, Jankowice, Marcel, Rydułtowy, B - study area coal mine Sośnica-Makoszowy 
characteristic feature of this series is the presence of claystone inserts with marine fauna that are used as correlation levels (Jureczka \& Kotas, 1995). The research materials were taken from the roof and base of coal seams, the coal seam 620 that represents the Poruba Beds (namurian A), constituting the highest part of the paralic series. The coal seam 620 was sampled in the coal mines 'Sośnica-Makoszowy', 'Marcel', and 'Rydułtowy'.

Limnic series (Upper Silesian sandstone series, mudstone series, and Cracow sandstone series) are characterised by diverse lithological development. The series of mudstone that is the subject of research is characterised by quite homogenous rock sequences. This series is composed mainly of mudstone and claystone with a few sandstone interlayers (Jureczka \& Kotas, 1995). The research materials were taken from the roof and base of coal seams; the coal seam 405 that represents the Zaleskie Beds (westphalian A) belongs to the mudstones series. The coal seam 405 was sampled in the following coal mines: 'Sośnica-Makoszowy', 'Chwałowice', and 'Jankowice'.

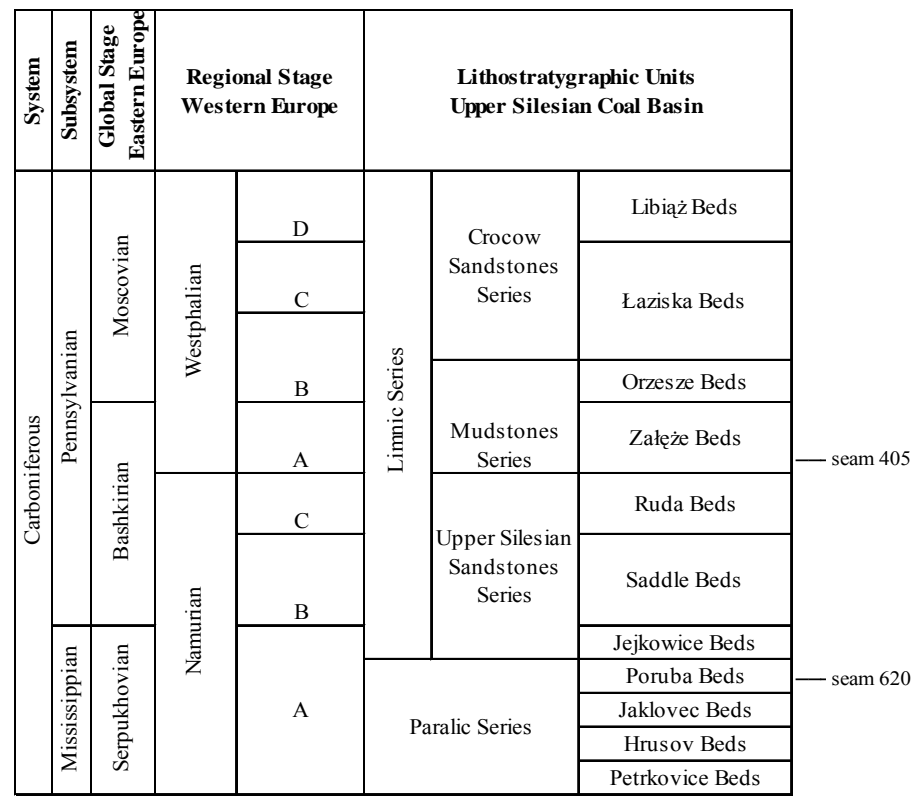

Fig. 2. Lithostratigraphic division of Carboniferous sediments in the Upper Silesian Coal Basin with the sampled coal seams (after: Buła \& Kotas, 1994)

The samples selected for the geochemical research represent a similar lithology (43 samples of claystone and two samples of sandy claystone). Twelve samples of the claystone were from the Poruba Beds of the paralic series, and 31 samples of the claystone and two samples of the sandy claystone were from the Zaleskie Beds of the limnic series.

For all samples, the concentration of main and trace elements was determined with the use of inductively coupled plasma mass spectroscopy (ICP-MS) in a Canadian laboratory, Activation Laboratories Ltd. (ACTLABS). The samples were prepared using multi-acid whole-rock digestion, (4-acid digestion) hydrofluoric acid (HF) + perchloric acid $\left(\mathrm{HClO}_{4}\right)+$ hydrochloric acid $(\mathrm{HCl})+$ nitric acid $\left(\mathrm{HNO}_{3}\right)$ were applied. 
For this paper, we chose trace elements and oxides that are mostly used in chemostratigraphy and identification of marine, brackish, and freshwater beds $\left(\mathrm{Cr}, \mathrm{Th}, \mathrm{U}, \mathrm{V}, \mathrm{AL}_{2} \mathrm{O}_{3}, \mathrm{MgO}\right.$, $\mathrm{K}_{2} \mathrm{O}$, and $\mathrm{P}_{2} \mathrm{O}_{5}$ ).

\section{Results of geochemical research from limnic and paralic series of the Upper Silesian Coal Basin}

43 samples of claystone and two samples of sandy claystone from the roof, floor, and bands of 620 (paralic series) and 405 (limnic series) coal seams were analysed. Basic petrological studies have shown the pelitic texture of the rock samples. The petrographic composition found the dominance of minerals of clayey minerals, with some admixtures of quartz, micas (biotite $>$ muscovite) and rare carbonates, mainly siderite. Moreover, they contain dispersed organic matter (coal).

The chemical composition of claystones is characterised by dominating presence of $\mathrm{SiO}_{2}$ among all determined components. The content of $\mathrm{SiO}_{2}$ is differentiated and varies from 45.5 to $54.5 \%$ in the sample from the pralic series, and from 44.6 to $61.3 \%$ in the sample from the limnic. The content of $\mathrm{Al}_{2} \mathrm{O}_{3}$ vary from 21.1 to $24.3 \%$ and, from 17.7 to $25.4 \%$ respectively.

The content of the other chemical components is similar in all samples.

Geochemical research has shown some differences in trace elements' concentrations.

In the samples from the Poruba Beds (coal seam 620), the average content of $U$ is equal to $6.3 \mathrm{ppm}$, and most of the $U$ can be interpreted as the authigenic $U$ (average $U_{\text {aut }}-3.9 \mathrm{ppm}$ ) not connected with detrital components (Tab. 1). Autogenic $U$ is connected mainly with organic

Geochemical ratio of samples from Poruba and Zaleskie Beds

\begin{tabular}{|c|c|c|c|c|c|c|c|c|}
\hline \multirow[b]{2}{*}{$\begin{array}{l}\text { Elements or } \\
\text { ratios }\end{array}$} & \multicolumn{4}{|c|}{ Zaleskie Beds (33 samples) } & \multicolumn{4}{|c|}{ Poruba Beds (12 samples) } \\
\hline & Mean & Min & Max & $\begin{array}{l}\text { Standard } \\
\text { deviation }\end{array}$ & Mean & Min & Max & $\begin{array}{l}\text { Standard } \\
\text { deviation }\end{array}$ \\
\hline $\mathrm{U}(\mathrm{ppm})$ & 4.8 & 3.2 & 6.6 & 0.9 & 6.3 & 5.7 & 7.1 & 0.4 \\
\hline $\mathrm{U}_{\text {aut }}(\mathrm{ppm})$ & 0.1 & 0.0 & 2.2 & 0.8 & 3.9 & 3.4 & 4.4 & 0.3 \\
\hline Th (ppm) & 14.1 & 10.2 & 22.5 & 3.1 & 7.3 & 6.4 & 9.1 & 0.7 \\
\hline $\mathrm{Th} / \mathrm{U}$ & 3.0 & 1.9 & 4.2 & 0.5 & 1.1 & 1.0 & 1.3 & 0.1 \\
\hline $\mathrm{K}_{2} \mathrm{O}(\%)$ & 3.3 & 2.3 & 4.4 & 0.4 & 1.7 & 1.3 & 2.3 & 0.3 \\
\hline $\mathrm{Th} / \mathrm{K}_{2} \mathrm{O}(\mathrm{ppm} / \%)$ & 4.3 & 3.0 & 9.7 & 1.2 & 4.4 & 3.2 & 5.5 & 0.7 \\
\hline $\mathrm{Al}_{2} \mathrm{O}_{3}(\%)$ & 23.4 & 17.7 & 25.9 & 1.8 & 22.4 & 21.1 & 24.3 & 1.0 \\
\hline $\mathrm{P}_{2} \mathrm{O}_{5}(\%)$ & 0.08 & 0.04 & 0.18 & 0.03 & 0.86 & 0.43 & 1.62 & 0.30 \\
\hline $\mathrm{P}_{2} \mathrm{O}_{5} / \mathrm{Al}_{2} \mathrm{O}_{3}$ & 0.004 & 0.002 & 0.007 & 0.001 & 0.038 & 0.018 & 0.073 & 0.014 \\
\hline $\mathrm{Cr}$ (ppm) & 111 & 85 & 128 & 9 & 53 & 39 & 65 & 7 \\
\hline $\mathrm{V}(\mathrm{ppm})$ & 143 & 104 & 180 & 16 & 168 & 139 & 247 & 31 \\
\hline $\mathrm{V} / \mathrm{Cr}$ & 1.3 & 1.0 & 1.8 & 0.1 & 3.3 & 2.3 & 6.3 & 1.0 \\
\hline $\mathrm{MgO}(\%)$ & 1.04 & 0.55 & 1.34 & 0.18 & 1.62 & 1.33 & 1.89 & 0.17 \\
\hline $\mathrm{MgO} / \mathrm{Al}_{2} \mathrm{O}_{3}$ & 0.04 & 0.03 & 0.06 & 0.01 & 0.07 & 0.06 & 0.09 & 0.01 \\
\hline $\mathrm{K}_{2} \mathrm{O} / \mathrm{Al}_{2} \mathrm{O}_{3}$ & 0.14 & 0.10 & 0.19 & 0.01 & 0.07 & 0.06 & 0.10 & 0.01 \\
\hline
\end{tabular}


substances (Algeo and Maynard, 2004; O'Mara and Turner, 1997; Taylor and McLennan, 1985) and seawater is indicated as the main source of $U$ (Taylor and McLennan, 1985).

In the samples from the Zaleskie Beds, the content of $U$ is lower at $4.8 \mathrm{ppm}$, and the content of the authigenic $U$ is very low (average $U_{\text {aut }}-0.13 \mathrm{ppm}$; Tab. 1). The participation of Th is expressed by an inverse relation. The concentration of this element in the Zaleskie Beds is $14.1 \mathrm{ppm}$ and is decisively higher than in the Poruba Beds at $7.3 \mathrm{ppm}$. The $T h / U$ ratio, depicted in literature as one of the most basic indicators identifying marine bands, is equal to 1.1 for Poruba Beds and 3.0 for Zaleskie Beds. The ratio of the content of those elements, illustrated by the graph, indicates the presence of two populations of samples, which clearly shows the distinctness of this ratio for samples from Poruba and Zaleskie Beds (Fig.3). The analysis of Th and U content in examined samples shows proper marine and non-marine environment of sedimentation, and the genesis of those beds connected with sediment conditions of paralic and limnic series.

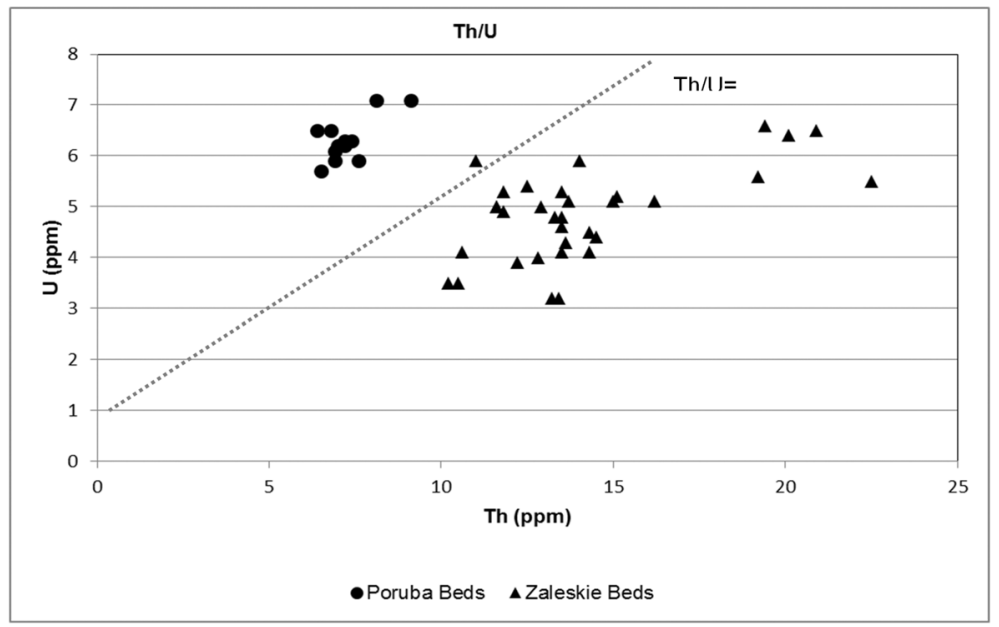

Fig. 3. Th/U ratio of samples from Poruba and Zaleskie Beds

Another indicator that is possibly useful in identification of marine sediments is the $\mathrm{Th} / \mathrm{K}_{2} \mathrm{O}(\mathrm{ppm} / \%)$ ratio. The average concentration of $\mathrm{K}_{2} \mathrm{O}$ in analysed samples from Poruba Beds is $1.7 \%$ and in samples from Zaleskie Beds $\mathrm{K}_{2} \mathrm{O}$ equals 3.3\%. The average value of the $\mathrm{Th} / \mathrm{K}_{2} \mathrm{O}$ indicator equals, respectively, 4.4 and 4.3 , indicating very similar values for paralic and limnic beds. The authors, in their preliminary research, noted that this ratio should be used cautiously for identification and correlation of the Upper Silesian Coal Basin deposits. Similar values of this ratio result from the fact that the increase of Th is accompanied by the increase of $\mathrm{K}_{2} \mathrm{O}$. The fact that both Th and $\mathrm{K}_{2} \mathrm{O}$ have a lower value in Poruba Beds than in Zaleskie Beds is also worth mentioning. It allows identifying these beds based on a relation between $\mathrm{Th}$ and $\mathrm{K}_{2} \mathrm{O}$ (Fig. 4).

The concentration of $\mathrm{P}_{2} \mathrm{O}_{5}$ was also analysed with the use of the $\mathrm{P}_{2} \mathrm{O}_{5} / \mathrm{Al}_{2} \mathrm{O}_{3}$ indicator. For the rock samples from the Poruba Beds, it is 0.038 and for Zaleskie Beds, it is 0.004 . According to Pearce et al. (2010), the value of the $\mathrm{P}_{2} \mathrm{O}_{5} / \mathrm{Al}_{2} \mathrm{O}_{3}$ indicator separating the marine sediments from limnic ones is $\mathrm{P}_{2} \mathrm{O}_{5} / \mathrm{Al}_{2} \mathrm{O}_{3}=0.02$. This indicator properly points to the sedimentary envi- 


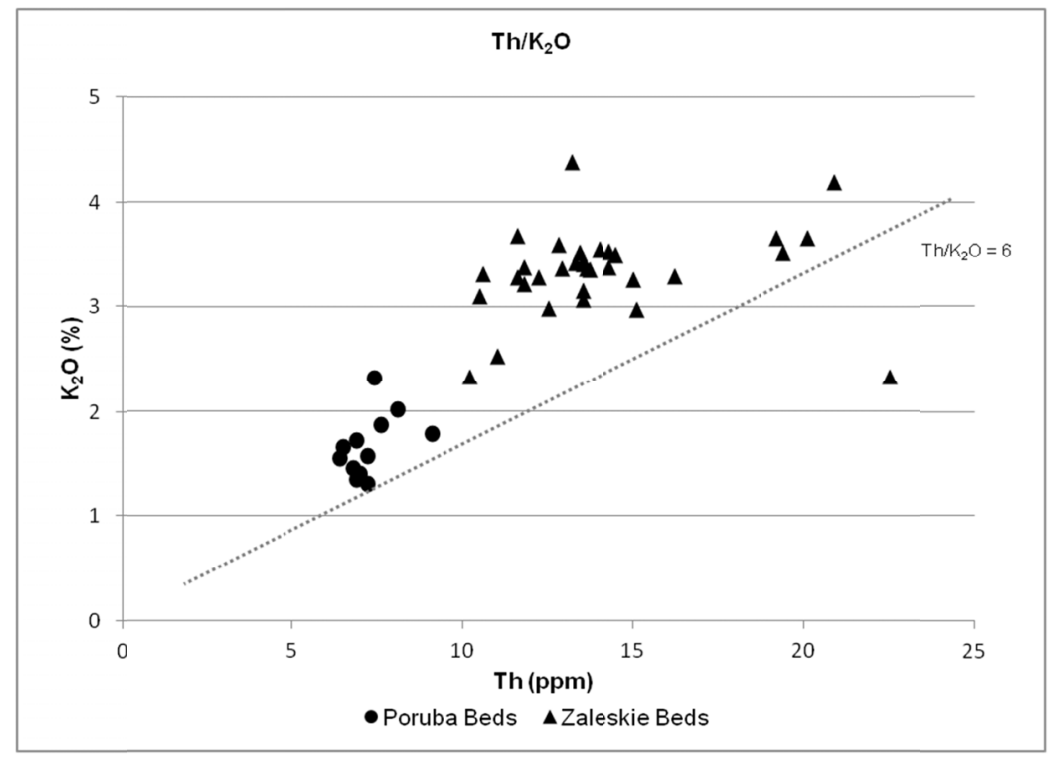

Fig. 4. $\mathrm{Th} / \mathrm{K}_{2} \mathrm{O}$ ratio of samples from Poruba and Zaleskie Beds

ronment of rocks originating from the paralic and limnic series of the Upper Silesian Coal Basin. The relation $\mathrm{P}_{2} \mathrm{O}_{5} / \mathrm{Al}_{2} \mathrm{O}_{3}$, depicted by the graph (Fig. 5), clearly points to two separate sets that represent Poruba and Zaleskie Beds.

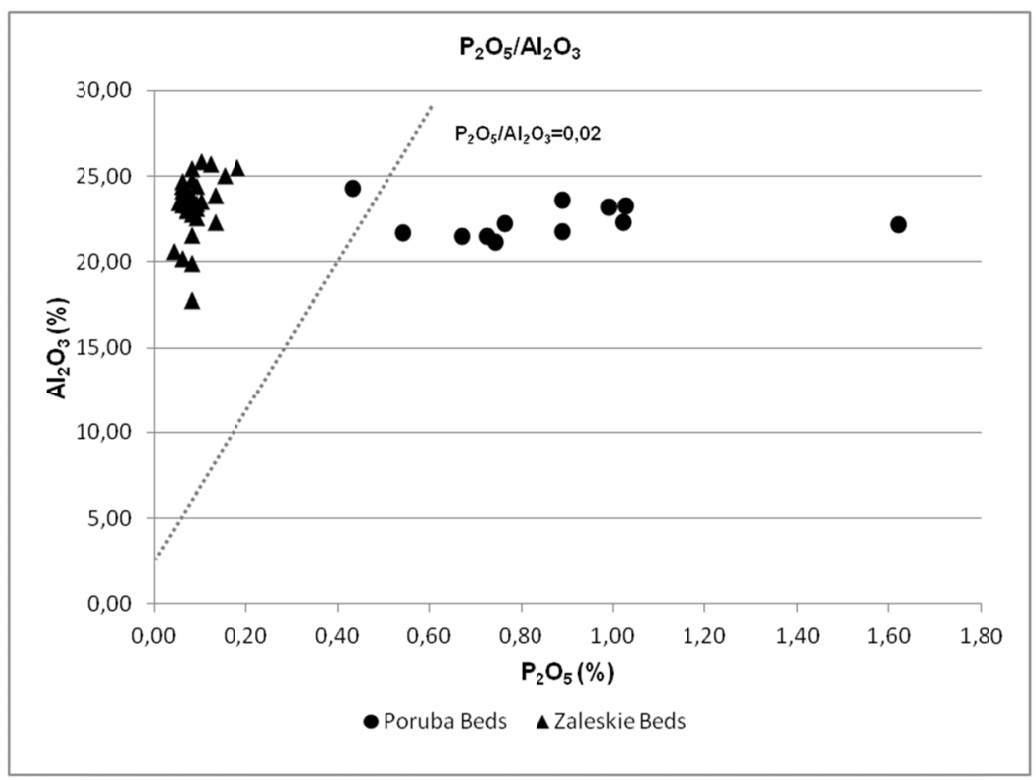

Fig. 5. $\mathrm{P}_{2} \mathrm{O}_{5} / \mathrm{Al}_{2} \mathrm{O}_{3}$ ratio of samples from Poruba and Zaleskie Beds 


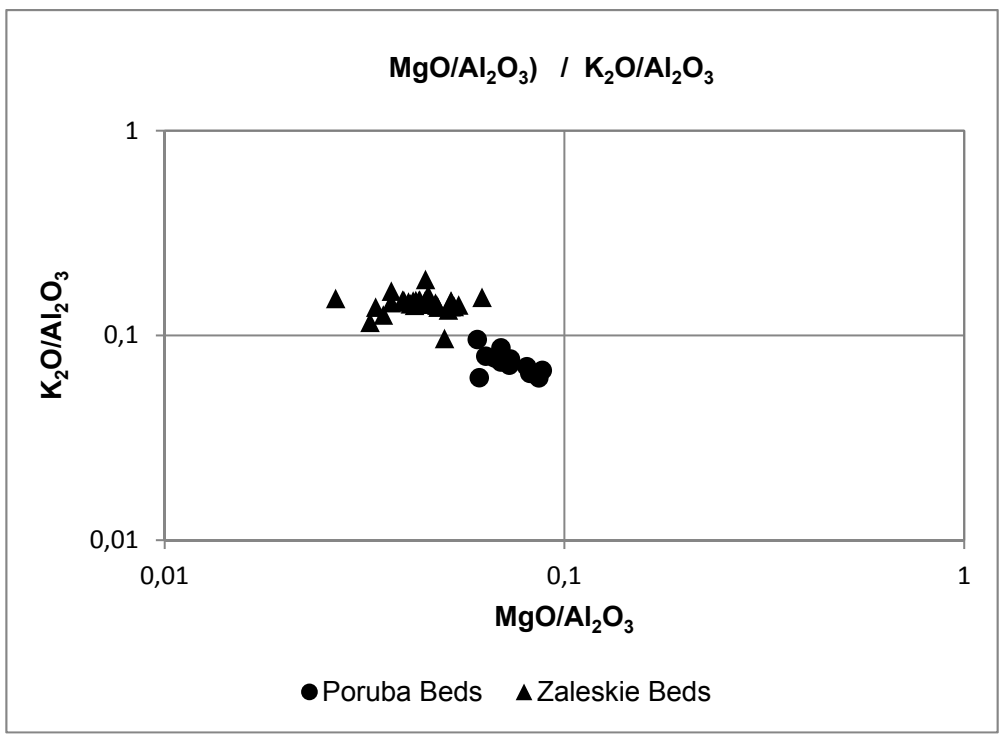

Fig. 6. $\mathrm{MgO} / \mathrm{Al}_{2} \mathrm{O}_{3}$ to $\mathrm{K}_{2} \mathrm{O} / \mathrm{Al}_{2} \mathrm{O}_{3}$ ratio for samples from Poruba and Zaleskie Beds

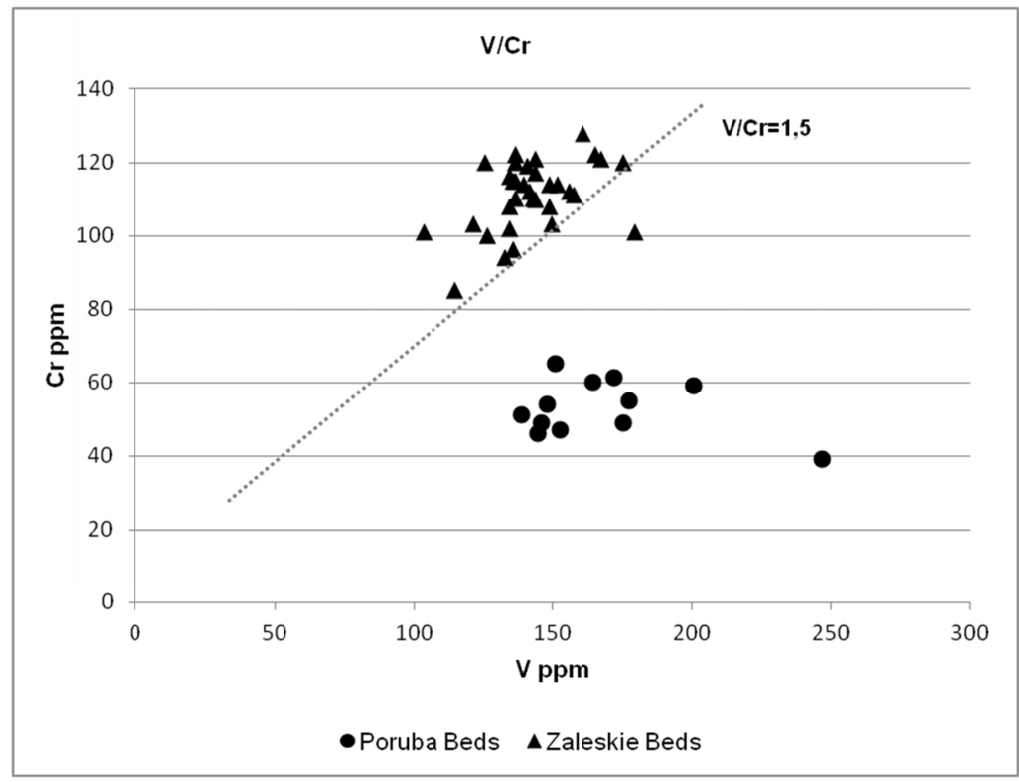

Fig. 7. V/Cr ratio for samples from Poruba and Zaleskie Beds

The diagram of the $\mathrm{MgO} / \mathrm{Al}_{2} \mathrm{O}_{3}$ to $\mathrm{K}_{2} \mathrm{O} / \mathrm{Al}_{2} \mathrm{O}_{3}$ ratio (Fig. 6), proposed by Roaldset (1978), clearly shows two populations with different genesis. The $\mathrm{MgO} / \mathrm{Al}_{2} \mathrm{O}_{3}$ value determines the sedimentary environment for Zaleskie Beds and equals 0.04 , which is below 0.05 and is typical 
for non-marine sediments. For Poruba Beds, it equals 0.07, suggesting a marine sedimentary environment.

An analysis of $\mathrm{V}$ and $\mathrm{Cr}$ values and their reciprocal relations in the analysed samples from the Upper Silesian Coal Basin was also conducted. The content of vanadium for Zaleskie Beds samples oscillates between 139 and $247 \mathrm{ppm}$, with an average value of $168 \mathrm{ppm}$, for Zaleskie Beds samples, it oscillates between 104 and $180 \mathrm{ppm}$ with the average value of $143 \mathrm{ppm}$. The higher participation of vanadium points to the marine genesis of deposits. The $\mathrm{V} / \mathrm{Cr}$ ratio was also analysed, which equals on average 3.3 for Poruba Beds and 1.3 for Zaleskie Beds. According to the literature, threshold value for marine and non-marine sediments equals $\mathrm{V} / \mathrm{Cr}=1.5$. The graph depicting the $\mathrm{V} / \mathrm{Cr}$ ratio clearly shows two populations of samples with different genesis (Fig. 7).

\section{Summary and discussion}

To assess the applications of usage of certain geochemical indices in chemostratigraphy of the Upper Silesian Coal Basin, geochemical analyses of samples taken from paralic and limnic series of the USCB were made. The parameters that are frequently used in inorganic geochemistry for identifying the marine and non-marine sediments were analysed: $U, T h, T h / U, K_{2} \mathrm{O}, T h / K_{2} \mathrm{O}$, $\mathrm{P}_{2} \mathrm{O}_{5}, \mathrm{Al}_{2} \mathrm{O}_{3}, \mathrm{P}_{2} \mathrm{O}_{5} / \mathrm{Al}_{2} \mathrm{O}_{3}, \mathrm{~V}, \mathrm{Cr}, \mathrm{V} / \mathrm{Cr}$, and $\left(\mathrm{K}_{2} \mathrm{O} / \mathrm{Al}_{2} \mathrm{O}_{3}\right) /\left(\mathrm{MgO} / \mathrm{Al}_{2} \mathrm{O}_{3}\right)$.

The indicators that are based on radioactive elements (U, Th) proposed by Adams and Weaver (1958), Archard and Trice (1990), Leeder et al. (1990); Davies and McLean (1996), O’Mara and Turner (1997), and Hollywood and Whorlow (1993) may be applied to the Carboniferous in the Upper Silesian Coal Basin. The content of $U$ in Poruba Beds (paralic series) equals an average of $6.3 \mathrm{ppm}$, so it is higher than the boundary $6.0 \mathrm{ppm}$ suggested by Davies and McLean (1996) and Leeder et al. (1990) as a bound for marine and non-marine sediments. The average value of the $T h / U$ ratio for the Poruba Beds equals 1.1 and is 3.0 for Zaleskie Beds. Because of that, as a boundary value of marine and non-marine sediments for the productive series of the USCB, the value of 2.0 after Adams and Weaver (1958) or the value of 3.0 after Hollywood and Whorlow (1993) and Kombrink et al. (2008) can be used.

According to the authors of this paper, another geochemical indicator, $\mathrm{Th} / \mathrm{K}_{2} \mathrm{O}\left(\mathrm{Th} / \mathrm{K}_{2} \mathrm{O}<6\right.$ for marine sediments), has limited usage for the rocks from the USCB. The average values of this indicator for Poruba and Zaleskie Beds are similar (4.4 and 4.3), which is connected to the fact that, in the examined samples, the growth of the Th value is accompanied by the growth of $\mathrm{K}_{2} \mathrm{O}$.

As an indicator of marine sediments, Pearce et al. (2010) gave the content of $\mathrm{P}_{2} \mathrm{O}_{5}$ expressed by the $\mathrm{P}_{2} \mathrm{O}_{5}$ to $\mathrm{Al}_{2} \mathrm{O}_{3}$ ratio, which is higher than 0.02 for marine sediments. This indicator is used in the analysis of the Upper Silesian Coal Basin deposits.

The essential indicator of marine and non-marine sediments is the $\left(\mathrm{MgO} / \mathrm{Al}_{2} \mathrm{O}_{3}\right) /\left(\mathrm{K}_{2} \mathrm{O} / \mathrm{Al}_{2} \mathrm{O}_{3}\right)$ ratio, in which the crucial meaning has the $\mathrm{MgO} / \mathrm{Al}_{2} \mathrm{O}_{3}$ value that, according to Roaldset (1978), is lower for the non-marine sediments $(<0.05)$. The analysis of this indicator for the Upper Silesian Coal Basin sediments showed its usability for the identification of the sedimentary environment.

The research conducted by the authors of this paper shows that samples of paralic series of the USCB are characterised by the higher content of V, similar to the marine sediments of Western Europe. The $\mathrm{V} / \mathrm{Cr}$ indicator is higher than 1.5 for marine sediments (Adamczyk, 1994; Dill et al., 1991) and in the case of samples from the Poruba Beds, it equals 3.27, confirming that this indicator may be used for the Upper Silesian Coal Basin deposits. 


\section{Conclusion}

The research shows that the geochemical character of rocks (claystone and sandy claystone) is different for Poruba Beds of the paralic series than for Zaleskie Beds of the limnic series. The analysis of the elements and their relationships allows distinguishing two populations representing paralic and limnic series. The research of certain geochemical indicators shows that indicators such as $\mathrm{U}, \mathrm{Th}, \mathrm{Th} / \mathrm{U}, \mathrm{P}_{2} \mathrm{O}_{5} / \mathrm{Al}_{2} \mathrm{O}_{3}, \mathrm{~V} / \mathrm{Cr}$, and $\left(\left(\mathrm{MgO} / \mathrm{Al}_{2} \mathrm{O}_{3}\right) /\left(\mathrm{K}_{2} \mathrm{O} / \mathrm{Al}_{2} \mathrm{O}_{3}\right)\right.$ may be used to identify the sedimentary environment and to correlate geochemical rock sequences in the Upper Silesian Coal Basin.

\section{References}

Adamczyk Z., 1998. Studium petrograficzne wkładek płonnych z pokładów węgla górnych warstw brzeżnych niecki jejkowickiej. Prace Geologiczne 144 - PAN. Wyd. Inst. Gospodarki Surowcami Mineralnymi i Energią PAN, Kraków.

Adams J.A, Weaver P.A., 1958. Thorium to uranium ratios as indicators of sedimentary processes: Examples of concept of geochemical facies. American Association of Petroleum Geologist, Bulletin 42, p. 387-430.

Alastuey A., Jimĕnes A., Plana F., Querol X., Suărez-Ruiz I., 2001. Geochemistry, mineralogy, and technological properties of the main Stephanian (Carboniferous) coal seams from the Puertollano Basin, Spain. International Journal of Coal Geology, 45, p. 247-265.

Algeo T.J., Maynard J.B., 2004. Trace-element behavior and redox facies in core shales of Upper Pennsylvanian Kansas-type cyclothems. Chemical Geology, 206, p. 289-318.

Archard G., Trice R.A., 1990. A preliminary investigation into the spectral radiation of the Upper Carboniferous marine bands. Newsletters on Stratigraphy, vol. 21, p. 167-173.

Breit G.N., Wanty R.B., 1991. Vanadium accumulation in carbonaceous rocks: A review of geochemical controls during deposition and diagenesis. Chemical Geology, Vol. 91, Issue 2, p. 83-97.

Buła Z., Kotas A., 1994. Geological Atlas of the Upper Silesian Coal Basin, Part III Structural Geological Maps. Geological Institute, Poland, Warsaw.

Chodyniecka L., 1973. Karbońskie sferosyderyty ilaste z Górnośląskiego Zagłębia Węglowego (Studium mineralogiczno-chemiczne). Zeszyty Naukowe Pol. Śl., seria: Górnictwo, z. 369.

Chodyniecka L., Biss D., Mikołajczyk P., 1994. Charakterystyka mineralogiczno-petrograficzna i możliwości wykorzystania przerostów występujących w niektórych pokładach węgla w KWK "Sośnica” (GZW). Zeszyty Naukowe Politechniki Śląskiej nr 1234, seria: Górnictwo, Gliwice, p. 16-30.

Davies S., McLean D., 1996. Spectral gamma ray and palynological characterisation of Kinderscoutian marine bands in the Namurian of the Pennine Basin, Yorkshire Geological Society, Proceedings, vol. 51, p. 103-114.

Diehl S.F., Goldhaber M.B., Hatch J.R., 2004. Modes of occurrence of mercury and other trace elements in coals from the warrior field, Black Warrior Basin, Northwestern Alabama. Internatinal Journal of Coal Geology, 59, p. 193-208.

Dill H., Teschner M., Wehner H., 1991. Geochemistry and lithofacies of Permo-Carboniferous carbonaceous rocks from the southwestern edge of the Bohemian Massif (Germany). A contribution to facies analysis of continental anoxic enwironments. International Journal of Coal Geology, 18, p. 251-291.

Dubiński J., Turek M., Aleksa H., 2005. Węgiel kamienny dla energetyki zawodowej w aspekcie wymogów ekologicznych. Prace Naukowe Głównego Instytutu Górnictwa, Górnictwo i Środowisko. Kwartalnik nr 2, p. 5-21.

Ehrenberg S.N., Siring E., 1992. Use of bulk chemical analysis in stratigraphic correlation of sandstones: an example from the Statfjord field, Norwegian continental shelf. Journal of Sedimentary Petrology, vol. 62, p. 318-330.

Grygar T., M., Popelka J., 2016. Revisiting geochemical methods of distinguishing natural concentrations and pollution by risk elements in fluvial sediments. Journal of Geochemical Exploration, 170, p. 39-57.

Hanak B., Kokowska-Pawłowska M., 2003. Charakterystyka zmienności udziału wybranych pierwiastków śladowych w skałach towarzyszacych pokładom węgla 610 i 620. Zeszyty Naukowe Politechniki Śląskiej nr 256, seria Górnictwo, p. 95-101. 
Hanak B., Kokowska-Pawłowska M., 2004. Zróżnicowanie zawartości pierwiastków śladowych i podrzędnych w skałach płonnych i popiołach węgla z pokład 620. Zeszyty Naukowe Pol. Śl., seria: Górnictwo, z. 260, p. 155-165.

Hanak B., Kokowska-Pawłowska M., 2006a. Zmienności zawartości pierwiastków śladowych w litotypach węgla i ich popiołach na tle profilów pokładu $630(G Z W)$. Gospodarka Surowcami Mineralnymi, t. 22, z. spec. 3, p. 69-77.

Hanak B., Kokowska-Pawłowska M., 2006b. Charakterystyka koncentracji pierwiastków śladowych w skałach towarzyszących z pokładu 630. Zeszyty Naukowe Politechniki Śląskiej nr 273, seria Górnictwo, p. 27-32.

Hollywood J.M., Whorlow C.V., 1993. Structural development andhydrocarbon occurrence of the Carboniferous in the UK Southern North Sea Basin. [In:] Parker, J.R., ed., Petroleum Geology of Northwest Europe: Proceedings of the Fourth Conference: Geological Society of London, p. 689-696.

Huggins F.E., Huffman G.P., 2004. How do lithophile elements occur in organic association in bituminous coals? International Journal of Coal Geology, 58, p. 193-204.

Jones B., Manning D.A.C., 1994. Comparison of geochemical indices used for the interpretation of palaeoredox conditions in ancient mudstones. Chem. Geol., vol. 111, p. 111-129.

Jureczka J., Kotas A., 1995. Upper Silesian Coal Basin in The Carboniferous system in Poland. Prace PIG, 168, p. $164-172$.

Kombrink H., van OS B.J.H., van der Zwan C.J., Wong Th.E., 2008. Geochemistry of marine and lacustrine bands in the Upper Carboniferous of the Netherlands. Netherlands. Journal of Geosciences - Geologie en Mijnbouw, p. 309-322.

Kotas A., 1982. Zarys budowy geologicznej GZW. Przewodnik 54 zjazdu PTG. Wydawnictwo Geologiczne, Warszawa, 45-72.

Kuhl J., Widawska J., Lach R., 1960. Wykorzystanie rentgenograficznych badań węgla dla celów przeróbki mechanicznej. Prace GIG. Komunikat nr 248. Katowice.

Leeder M.R., Raiswell R., Al-Biatty H., McMahon A., Hardmann M., 1990. Carboniferous stratigraphy, sedimentation and correlation of well 48/3-3 in the southern North Sea Basin: integrated use of palynology, natural gamma/sonic logs and carbon/sulfur geochemistry. Geological Society of London, Journal, vol. 147, p. 287-300.

Lewińska-Preis L., Biedroń J., Fabiańska M., 2001. Geochemiczna ocena rozkładu stężeń pierwiastków śladowych we frakcjach węgla kamiennego poddanego procesowi bioodsiarczania. Zeszyty Naukowe Politechniki Śląskiej, Seria: Górnictwo, z. 249.

Liu D., Yang Q., Tang D., Kang X., Huang W., 2001. Geochemistry of sulphur and elements in coals from the Antaibao surface mine, Pingshuo, Shanxi Province, China. International Journal of Coal Geology, 46, p. 51-64.

Mielecki T., Krzyżanowska W., 1961. Charakterystyka chemiczna popiołów węgli górnośląskich. Monografia Polskich Węgli, Komunikat 273, Katowice.

Olkuski T., Stala-Szlugaj K., 2009. Występowanie pierwiastków promieniotwórczych $w$ węglach kamiennych pochodzacych $z$ GZW, w skałach przyweglowych, w wodach kopalnianych oraz w odpadach. Gospodarka Surowcami Mineralnymi, t. 25, z. 1, p. 2-14.

O’Mara P.T., Turner B.R., 1997. Westphalian B marine bands and their subsurface recognition using gamma-ray spectrometry. Yorkshire Geological Society, Proceedings, p. 307-316.

Parzentny H., 1989a. Różnice w zawartości i sposobie związania niektórych pierwiastków w węglu Górnośląskiego Zagtębia Węglowego w profilu pojedynczego pokładu. Przegląd Górniczy, nr 4, p. 17-21.

Parzentny H., 1989b. Zwiąek miedzi, kobaltu i niklu z organiczna i mineralną substancją węgla ze wschodniej części Górnośląskiego Zagłębia Węglowego. Przegląd Górniczy, nr 6, p. 20-23.

Parzentny H., 1990. Rola substancji mineralnej w kształtowaniu zawartości cynku, ołowiu i kadmu w węglu ze wschodniej części Górnośląskiego Zagłębia Węglowego. Przegląd Górniczy, nr 3, p. 16-19.

Parzentny H., 1991. Zróżnicowanie zawartości ołowiu w węglach i tupkach węglowych z facji limnicznej po rozciągłości Górnośląskiego Zagłębia Węglowego. Przegląd Górniczy, nr 6, p. 33-36.

Parzentny H., 1999. Petrograficzna i geofizyczna charakterystyka skupień nieorganicznej substancji mineralnej w pokładzie węgla 504 w rejonie Czeladzi. Przegląd Górniczy, nr 10, p. 32-40.

Pearce T.J., Besly B.M., Wray D., Wright D.K., 1999. Chemostratigraphy: a method to improve interwell correlation in Barren sequences - a case study using onshore Duckmantian/Stephanian sequences (West Midlands, U.K.). sedimentary environment sedimentary environment sedimentary environment ary Geology, vol. 124, p. 197-220.

Pearce T.J., Mclean D., Wright D.K., Jeans C.J., Mearns E.W., 2005a. Stratigraphy of the Upper Carboniferous Schooner Formation, southern North Sea: chemostratigraphy, mineralogy, palynology and Sm-Nd isotope analysis. [In:] Collinson, J.D., Evans, D.J., Holliday, D.W., and Jones, N.S., eds., Carboniferous Hydrocarbon Geology: The 
Southern North Sea and Surrounding Onshore Areas: Yorkshire Geological Society, Occasional Publications Series no. 7 , p. $165-182$.

Pearce T.J., Wray D.S., Ratcliffe K.T., Wright D.K., Moscariello A., 2005b. Chemostratigraphy of the Upper Carboniferous Schooner Formation, southern North Sea. [In:] Collinson, J.D., Evans, D.J., Holliday, D.W., and Jones, N.S., eds., Carboniferous Hydrocarbon Geology: The Southern North Sea and Surrounding Onshore Areas: Yorkshire Geological Society, Occasional Publications Series no. 7, p. 47-164.

Pearce T.J., McLean D., Martin J.H., Ratcliffe K., Wray D.S., 2010. A whole-rock geochemical approach to the recognition and correlation of "Marine Bands". Society for Sedimentary Geology, p. 221-238.

Racey A., Love M.A., Bobolecki R.M., Walsh J.N., 1995. The use of chemical element analysis in the study of biostratigraphically barren sequences: an example from the Triassic of the central North Sea (UKCS). [In:] Dunay, R.E., and Hailwood, E.A., eds., Non-Biostratigraphical Methods of Dating and Correlation: Geological Society of London, Special Publication 89, p. 69-105.

Ratcliffe K.T., Wright A.M., Hallsworth C., Morton A., Zaitlin B.A., Potocki D., Wray D.S., 2004. Alternative correlation techniques in the petroleum industry: an example from the (Lower Cretaceous) Basal Quartz, Southern Alberta. American Association of Petroleum Geologists, Bulletin, vol. 88, p. 1419-1432.

Ratcliffe K.T., Hughes A.D., Lawton D.E., Wray D.S., Bessa F., Pearce T.J., Martin J., 2006. A regional chemostratigraphically-defined correlation framework for the late Triassic TAG-I in Blocks 402 and 405a, Algeria. Petroleum Geoscience, vol. 12, p. 3-12.

Ratcliffe K.T., Morton A., Ritcey D., Evenchick C.E., 2008. Whole rock geochemistry and heavy mineral analysis as exploration tools in the Bowser and Sustut Basins, British Columbia, Canada. Bulletin of Canadian Petroleum Geology, v. 55, p. 320-337.

Roga B., Ihnatowicz A., Węclewska M., Ihnatowicz M., 1958. Badania nad zawartością boru w polskich węglach. Prace GIG, Komunikat nr 212, Katowice.

Roaldset E., 1978. Mineralogical and chemical changes during weathering, transportation and sedimentation in different environments with particular references to the distribution of Yttrium and lanthanide elements. Ph.D. Thesis, Geol. Inst., Univ. of Oslo, Norway.

Różkowska A., 1993. Pierwiastki podrzędne i śladowe w węglu z głębokich poziomów karbonu produktywnego Górnośląskiego Zagtębia Węglowego (GZW). Przegląd Geologiczny, vol. 41, nr 11, p. 780-784.

Różkowska A., Ptak B., 1995. Pierwiastki podrzędne i śladowe w górnośląskich węglach kamiennych. Przegląd Geologiczny, vol. 43, nr 6, p. 478-481.

Ryczek M., 1959. Występowanie germanu i galu w węglu kamiennym oraz sposoby jego wzbogacania. Przegląd Górniczy $\mathrm{nr} 9$.

Spears D., 1965. Boron in some British Carboniferous sedimentary rocks. Geochemica Cosmochimica Acta, nr 28 p. 315-328.

Taylor S.R., McLennan S., 1985. The continental crust its composition and evolution. Blackwell, Oxford, pp. 312

Tribovillard N., Algeo T.J., Lyons T., Riboulleau A., 2006. Trace metals as paleoredox and paleoproductivity proxies: An update. Chemical Geology, 232, p. 12-32.

Widawska-Kuśmierska J., 1981. Występowanie pierwiastków śladowych w polskich węglach kamiennych. Przegląd Górniczy, nr 7-8, t. XXXVII, p. 455-459.

Wignall P.B., Myers K.J., 1988. Interpreting benthic oxygen levels in mudrocks: a new approach. Geology, vol. 16, p. 452-455.

Winnicki J., 1973. Występowanie i sposób zwiąania niektórych pierwiastków rzadkich w krajowych węglach kamiennych. Prace Naukowe Instytutu Chemii Nieorganicznej i Metalurgii Pierwiastków Rzadkich. Konferencje nr 8, p. 3-71.

Wray D.S., 1999. Identification and long-range correlation of bentonites in Turonian-Coniacian (Upper Cretaceous) chalks of northwest Europe. Geological Magazine, vol. 136, p. 361-371.

Xu G., Hannah, J.L., Bingen B., Georgiev S., Stein H., J., 2012. Digestion methods for trace element measurements in shales: Paleoredox proxies examined. Chemical Geology, 324-325, p. 132-147.

Zhang J., Ren D., Zhu Y., Chou Ch., Zeng R., Zheng B., 2004. Mineral matter and potentially hazardous trace elements in coals from Qianxi Fault Depression Area in southwestern Guizhou, China. International Journal of Coal Geology, 57, 49-61. 